\title{
People's Sense of Security about Crime: Analysis the Brazilian Case
}

\author{
Vasconcelos Reis Wakim ${ }^{1, *}$, Elizete Aparecida de Magalhães ${ }^{1}$, João Eustáquio de Lima ${ }^{2}$, Vivani Silva Lírio ${ }^{3}$ \\ ${ }^{1}$ Federal University of the Valleys of Jequitinhonha and Mucuri, Packed in the Accounting Department \\ ${ }^{2}$ Universidade Federal de Viçosa, Crowded in the Department of Rural Economics \\ ${ }^{3}$ Federal University of Viçosa, Crowded in the Department of Rural Economics \\ *Corresponding author: vasconcelos.wakim@ufvjm.edu.br
}

\begin{abstract}
Given the crime has grown in the last's three decades, and that crime reduces the well-being of the individual who constitutes victim, the present study seeks to analyze the determinants of the feeling of security of the people in the city in which it resides, in the year 2009. The estimation of the sense of security was carried out based on the model logit. Among the variables inserted in the model, most of it was significant and presented effect according to economic theory. The factors that presented the most relevant impact were: victim of the robe, resident in the urban area and kind of domicile. It is concluded that, based on the results, the adoption of public policies focused on prevention and combating crime is fundamental, so that the portion of the population that feels insecure reduces, making there an improvement in the quality of life of society regarding wellbeing.
\end{abstract}

Keywords: economics of crime, crime, the sense of security

Cite This Article: Vasconcelos Reis Wakim, Elizete Aparecida de Magalhães, João Eustace de Lima, and Vivani Silva Law, "People's Sense of Security about Crime: Analysis Do Brazilian Case." Journal of Finance and Economics, vol. 6, no. 3 (2018): 103-110. doi: 10.12691/jfe-6-3-4.

\section{Introduction}

Criminal activities generally cause an economy for society, implying in loss of welfare, and the criminal actions are measured by the quantitative infractions [1]. It is understood that concern about crime-related issues is not recent, that is, more than 40 years ago there is a debate about crime and its implications on the well-being of individuals.

According to the Institute of Applied Research and Economics [2]; Waiselfisz [3], the number of violent mortality (murder) grew in the period from 1980 to 2012 about $305 \%$, being 4.8 times higher than the growth of the Brazilian population in the same period. Compared to other countries, Brazil occupies the seventh world position, presenting a homicide rate relative to the total population of $27.4 \%$.

It should be noted that criminal actions are not only numerous but also extremely diversified. These actions affect people in their different activities and from various social backgrounds, levels of education, ages, races, etc. [1].

As Becker [1] it is important that the initiative of the public and private sector invest resources in actions that can minimize the problems caused by the crime. Public and private resources are generally spent, both to prevent crimes and to combat criminal actions. It stands out that the word crime can take on several meanings such as murder, robbery, and assault, crimes of tax evasion, whitecollar crimes, among other conceptions.

According to Araújo and Ramos [4] "The growth of crime in Brazil, especially in recent years has been drawing the attention of governmental and non-governmental institutions, researchers from various areas of knowledge and civil society." Silva and Beato Filho (2013) add that with the increase in crime, as well as violence in the urban environment, the feeling of fear of people and even the sense of security decreases, especially in large urban centers.

With the increase in the victim number of homicides, from the decade of 1980, and considering that the perception of individuals about their safety in the community and/or city interferes with the quality of life of people, to conduct studies on the perception of people in That concerns the sense of security in the environment in which it lives is relevant. This is important because it is possible to give subsidies to the definition and formulation of public policies to prevent and reduce crime, to improve the safety of people, thereby reducing the sense of fear of individuals.

Alkimim, Clarke, and Oliveira [5] comment that crime and violence prevent individuals from taking advantage of all the benefits provided by cities because they seek refuge in their homes to protect themselves from the actions of criminals. Thus, they make their homes in small fortresses against the criminals, demonstrating a great sense of insecurity.

In the literature, studies are observed that analyze crime from those who commit the crime, seeking to identify the factors that lead an individual to a crime, as well as analysis of the rate of homicides. However, debates focusing on the perception of the individual as to the fear of being a victim in their domicile, neighborhood or even 
city are limited. In the face of the above, the central question of this research is to understand the factors that interfere with the feeling of security of individuals in the city in which they reside. Thus, the present work aims to analyze the elements that determine the sense of security of people in what they say return to crime in Brazil, in the year 2009 .

\section{Crime and the Fear of Crime}

Economic science, besides worrying about several macroeconomic issues, in recent years has discussed issues related to inequality, health, education, poverty as well as a crime [6]. In this sense, Araújo and Ramos [4], say that for many years, issues such as inflation, high interest rates, unemployment and other economic problems constituted the focus of discussion. They emphasize that recent crime-related issues have taken over the economic debates.

Leal (2012) explains that regardless of the conceptual structure used, causing certain chaos and attempting to the social order. Foster Giles-Corti and Knuiman [7] argue that many crimes happen for opportunity issues in which the criminal subjects analyze the activities people's daily activities, which includes routines, travel and other when they discover potential targets. The theory of crime suggests three elements needed for that a felony can occur: a criminal; a target and; the absence of a guardian.

In the vision of Santos and Kassouf [6], an individual acting rationally, "He will commit a crime if and only if the usefulness expected by him exceeds the usefulness he would have in allocating his time and other resources in activities that are lawful." The authors add that some people commit crimes, not because their motivations differ from those of other people, but because of the reason the costs and benefits are different. Thus, the focus of the economic studies is in the decision of the individuals, since they make choices. The idea is corroborated by Cerqueira and Lobão [8] by mentioning that the decision of the individual to practice a certain crime stems from the maximization of the user since it would compare the possible gains of the practice of crime with the expected cost of such criminal activity.

When you talk about crime and feeling of security, it is essential that you have information about the nature of the crime so that the authorities can implement measures to reduce crimes in general. Thus, the role of the victim in this process is essential, because without information from the population it is difficult to develop effective actions to control crime. In this sense, Carneiro [9] comments that the information provided by the victims of the crime is relevant to the crime-fighting policies. It complements saying that the crimes that cause a greater sense of insecurity are those related to homicide, assault, rape, and theft.

However, the victims of certain crimes, afraid of being persecuted, they fail to record that he was the target of crime, violence or other crime-related acts. The fact makes the feeling of security decrease, interfering with their quality of life since the fear of crime can affect the population, restricting their daily activities and even increasing their spending safely in residences. The fear of crime, like San Juan, Vozmediano, and Vergara [10], makes the citizen's right to move freely by the public thoroughfares in the urban environment does not affect satisfactorily, generating a loss of quality of urban life. Hicks and Brown [11] complement, by stating that quality of life is adversely affected by the fear of crime and the lack of personal security.

In the conception of Leal (2012, p. 404) "The feeling of insecurity does not result only from the experiences of victimization or the likelihood of being able to be victimized by an act criminal, but also of the informative and media dynamics transmitted live and in Direct By the media." They add that the feeling of insecurity depends on the way the public power, as well as the media, treat the subject. Hanslmaier [12] identifies that agents accompanying newspapers are more affected by crime rates since they have more information about local crime.

From the study developed by Becker [1] that addresses on the theory of crime, several works were carried out mainly in the sense of identifying what leads an individual to commit a crime or even about the fear of being the target of the crime. The study carried out by the author analyses issues related to the benefits and costs of criminal actions. As far as the fear of crime is concerned, San-Juan, Vozmediano, and Vergara [10] have stated that the subject of fear of crime has been researched by several areas since 1970 , but the results achieved many of the times are divergent, hampered the proposition of actions and policies.

Silva and Beato Filho (2013, p. 157), while discourse on the fear of crime stress that as a subjective measure of perception of the environment, fear does not boil down to a real likelihood of an individual being a victim of a crime and should include The reactions or attitudes taken by people because of this feeling." They also mention that people reveal fear through attitudes and behaviors.

Silva and Beato Filho (2013) developed a study on the fear of crime for the municipality of Belo Horizonte, from the Survey of victimization, carried out by the Center for Crime and Public Safety Studies- Crisp/UFMG, in 2006. They estimated a multilevel regression model in which they analyzed a fixed-effect analysis at the individual and neighborhood level. The authors concluded that the female and the older people present a direct relationship with the fear of crime and the residential stability has a different effect. Regarding neighborhood level, they found that social cohesion among residents of a neighborhood has a direct relationship between the crime rate and the fear of crime.

The theme was also studied by Araújo and Ramos [4], in which they sought to identify the impact of crime on individual and social well-being, as well as the constraints of the feeling of insecurity. To do so, they applied questionnaires in the city of João Pessoa-Paraíba for capturing the willingness to pay DAP of people through a series of security services. The provision to be paid was carried out through the model Logit. The authors found that the variables that denote people living at home classify their neighborhood with an average level of security, in which the feeling of insecurity has been increasing in recent years and time of residence contribute to the insecurity of the individual. They concluded that DAP reflects on the level of insecurity of individuals and that the estimation of loss of welfare benefits the reduction of loss of people for lethal crimes and health spending. 
Hanslmaier [12] analyzes the consequences of crime in the daily life of people, relating the fear of crime and the satisfaction of life. In the research carried out in Germany in 2010, it incorporates the media as an important source of information on crime for society. It is noted that the fear of crime and the victim's experience with crime diminishes the life satisfaction of the researched and that the local crime rate aggravates the fear of crime. Another finding of the research is that the fear of crime depends on how people are informed by the media about crime rates.

In describing the causes of crime, Cerqueira, and Lobão [8], comment on the habits and routines of life of individuals. The authors argue that if the individual invests in the protection, it lessens the chance of the aggressor. That is, if the person practices a leisure activity within their home or condominium, it will tend to be less victimized by those who develop some activity in public environments. Also, individuals who work at home or live with other people, compared to those who work outside or live alone are less likely to be the target of the crime.

Lindström et al. [13] mention that the fear of crime or feeling of insecurity in public places, regardless of the type of crime, constitutes a direct physical and psychological trauma to the individual victims of crime. The sense of insecurity in the neighborhood and other public places has an association with age, sex, education and social networking.

\section{Methodological Procedures}

To identify the variables that explain the sense of security, the model Logit was used. The said model has been widely employed in research that analyzes qualitative choice, that is, it aims to explain certain attribute of the sample, is frequently used in studies like this research. The work of Araújo and Ramos [4] is cited Beato Filho, Peixoto and Andrade (2004). The first study analyzes the effect of crime on the well-being of people and the second aims to identify the victim's profile by type of crime.

According to Gujarati and Porter [14], the Model Logit That aims to identify the probability and the Fact occurring uses the accumulated density function and can be written as:

$$
P_{i}=\frac{1}{1+e^{-X_{i} \beta}}
$$

In which $P_{i}$ Represents the logistics distribution function, $X_{i}$ is the variable vector Independent $\beta$ is the parameter vector and $e$ This is the basis of the natural logarithm. So, the binary model is a choice between two mutually exclusive alternatives. The variable considered dependent (Yi) assumes a value equal to 1 if the investigated event occurs and 0 , otherwise.

In the model Logit, because it is not a linear function, the effect of independent variables on the dependent variable cannot be interpreted directly. Thus, it should be analyzed the marginal effect that measures the impact of variation of a unit in the explanatory variable on the likelihood of occurrence of the event, in the case of a continuous variable. When it comes to binary variables, the marginal effect measures the effect on probability when the variable goes from zero to one. Therefore, the marginal effects of the explanatory variables on the dependent variable can be obtained in the model Logit by the equation 2 .

$$
E M_{X j}=\beta_{k} P_{i}\left(1-P_{i}\right)
$$

The function Logit To explain the constraints of the feeling of security of the people who constituted the sample, in Brazil, it was defined as:

$$
\begin{aligned}
Y_{i}= & \alpha_{0}+\alpha_{1} S S D_{i}+\alpha_{2} I D_{i}+\alpha_{3} S_{i}+\alpha_{4} E C_{i} \\
& +\alpha_{5} E D C_{i}+\alpha_{6} R D P_{i}+\alpha_{7} V R_{i}+\alpha_{8} U R_{i} \\
& +\alpha_{9} R N G_{i}+\alpha_{10} L R P D_{i}+\alpha_{11} R N_{i} \\
& +\alpha_{12} R N E_{i}+\alpha_{13} R C O_{i}+\alpha_{14} R S E_{i} \\
& +\alpha_{15} V A V P_{i}+\alpha_{16} V A O L_{i}+\alpha_{17} L G S P C_{i} \\
& +\alpha_{18} T D_{i}+\alpha_{19} \text { FCFM }_{i}+\alpha_{20} \text { FCFMA }_{i} \\
& +\alpha_{21} \text { OTF }_{i}+\alpha_{22} \text { PDOM }_{i}+\varepsilon_{i}
\end{aligned}
$$

\begin{tabular}{|c|c|c|}
\hline $\begin{array}{l}\text { Dependent } \\
\text { variable }\end{array}$ & Description & Unit \\
\hline$Y$ & $\begin{array}{c}\text { Feeling of security in the city: assumes value } \\
\text { one if the individual feels safe and } 0, \\
\text { otherwise }\end{array}$ & Dummy \\
\hline Explanatory & Description & - \\
\hline SSD & $\begin{array}{l}\text { Home Security System: assumes value } 1 \text { for } \\
\text { households that have some safety device }\end{array}$ & Dummy \\
\hline ID & $\begin{array}{l}\text { Age of the individual: assumes value } 1 \text { for } \\
\text { people aged between } 17 \text { and } 29 \text { years }\end{array}$ & In years \\
\hline $\mathrm{S}$ & Gender: Assumes value 1 for male people & Dummy \\
\hline $\mathrm{EC}$ & $\begin{array}{l}\text { Marital Status: Assumes value } 1 \text { for married } \\
\text { people }\end{array}$ & Dummy \\
\hline EDC & Education & In years \\
\hline LRDP & $\begin{array}{c}\text { Household Monthly Income Per capita, in } \\
\text { logarithm }\end{array}$ & In real \\
\hline VR & $\begin{array}{c}\text { Theft Victim: Assumes value } 1 \text { for } \\
\text { individuals who have already been the victim } \\
\text { of theft }\end{array}$ & Dummy \\
\hline UR & $\begin{array}{c}\text { Resident in the urban area: assumes value } 1 \\
\text { for the individual who resides in the urban } \\
\text { area }\end{array}$ & Dummy \\
\hline RBRA & White and Yellow race & Dummy \\
\hline RNG & Black race & Dummy \\
\hline RPD & Brown race & Dummy \\
\hline $\mathrm{RN}$ & $\begin{array}{l}\text { North region: Assumes value } 1 \text { for people } \\
\text { residing in the north }\end{array}$ & Dummy \\
\hline RNE & $\begin{array}{l}\text { Northeast Region: Assumes value } 1 \text { for } \\
\text { people who reside northeast }\end{array}$ & Dummy \\
\hline $\mathrm{RCO}$ & $\begin{array}{l}\text { Midwest Region: Assumes value } 1 \text { for } \\
\text { individuals living in the Midwest }\end{array}$ & Dummy \\
\hline $\mathrm{RS}$ & $\begin{array}{l}\text { South Region: Assumes value } 1 \text { for people } \\
\text { residing in the southern states }\end{array}$ & Dummy \\
\hline RSE & $\begin{array}{c}\text { Southeast Region: Assumes value } 1 \text { for } \\
\text { people living in the southeast }\end{array}$ & Dummy \\
\hline VAVP & Assault victim on public roads & Dummy \\
\hline VAR & Assault victim at the residence & Dummy \\
\hline VAOL & Assault victim in other locations & Dummy \\
\hline LGSPC & $\begin{array}{c}\text { Spending on public safety Per capita, in } \\
\text { logarithm }\end{array}$ & In real \\
\hline $\mathrm{TD}$ & $\begin{array}{l}\text { Type of domicile: assumes value } 1 \text { for } \\
\text { individuals residing at home }\end{array}$ & Dummy \\
\hline FSF & Families without children & Dummy \\
\hline FCFME & Families with children under the age of 14 & Dummy \\
\hline FCFMA & Families with children older than 14 years old & Dummy \\
\hline OTF & Other types of families & Dummy \\
\hline PDOM & People at home & Amount \\
\hline
\end{tabular}

The variables entered in the estimated model are described in the 1 .

Table 1. Model variables

Source: Own Elaboration 
The data to achieve the objective of this study were collected in the national research by a sample of households (PNAD) of 2009 made available by the Brazilian Institute of Geography and Statistics (IBGE). The choice of the analysis period is due to the availability of data relating to victimization and justice only in 2009, the year in which IBGE published the basic research Microdata and Supplementation of Victimization and Justice. The estimation of the sense of security in the city, considering the Brazilian states, had as a sample of people of ten years or more of age, constituting 324,100 observations.

The data relating to the variable spent on public security of the year 2009 were obtained with the system of the National Treasury Secretariat. The expenditure involves expenses of public entities with policing, Civil defense and intelligence. The population of the States was collected in the IBGE, using the Number of inhabitants of 2010.

Table 2 shows the values of the average, minimum, maximum and standard deviation of the sample used in the estimation of this study.

Table 2. Descriptive analysis of the variables used in the estimation

\begin{tabular}{|c|c|c|c|c|}
\hline Variables & Average & $\begin{array}{l}\text { Standard } \\
\text { deviation }\end{array}$ & Minimum & Maximum \\
\hline $\begin{array}{l}\text { System Security at the } \\
\text { Dom. }\end{array}$ & 0,370 & 0,483 & 0,000 & 1,000 \\
\hline $\begin{array}{l}\text { Age (between } 17 \text { and } 29 \\
\text { years) }\end{array}$ & 0,268 & 0,443 & 0,000 & 1,000 \\
\hline Sex & 0,481 & 0,500 & 0,000 & 1,000 \\
\hline Marital status & 8,181 & 0,489 & 0,000 & 1,000 \\
\hline Education & 1,100 & 4,397 & 1,000 & 17,000 \\
\hline $\begin{array}{l}\text { Household income Log } \\
\text { Per capita }\end{array}$ & 0,043 & 0,494 & 0,000 & 1,946 \\
\hline Robbery victim & 0,847 & 0,202 & 0,000 & 1,000 \\
\hline $\begin{array}{l}\text { Resident in the urban } \\
\text { area }\end{array}$ & 0,080 & 0,360 & 0,000 & 1,000 \\
\hline Black race & 0,471 & 0,271 & 0,000 & 1,000 \\
\hline Brown race & 0,129 & 0,499 & 0,000 & 1,000 \\
\hline Northern Region & 0,315 & 0,336 & 0,000 & 1,000 \\
\hline Northeast Region & 0,110 & 0,465 & 0,000 & 1,000 \\
\hline Midwest Region & 0,290 & 0,313 & 0,000 & 1,000 \\
\hline Southeast Region & 0,031 & 0,454 & 0,000 & 1,000 \\
\hline $\begin{array}{l}\text { Assault victim public } \\
\text { thoroughfares }\end{array}$ & 0,006 & 0,173 & 0,000 & 1,000 \\
\hline $\begin{array}{l}\text { Victim of Murde Other } \\
\text { Locations }\end{array}$ & 5,039 & 0,080 & 0,000 & 1,000 \\
\hline $\begin{array}{l}\text { Log of the expense with } \\
\text { Sec. Public. Per capita }\end{array}$ & 0,907 & 0,342 & 4,357 & 5,860 \\
\hline Type of Home & 0,246 & 0,291 & 0,000 & 1,000 \\
\hline $\begin{array}{l}\text { Family with child }<14 \\
\text { years }\end{array}$ & 0,339 & 0,431 & 0,000 & 1,000 \\
\hline $\begin{array}{l}\text { Family with son > } 14 \\
\text { years }\end{array}$ & 0,275 & 0,473 & 0,000 & 1,000 \\
\hline Another type of family & 3,634 & 0,446 & 0,000 & 1,000 \\
\hline $\begin{array}{l}\text { Number of people at } \\
\text { home }\end{array}$ & 0,031 & 1,544 & 1,000 & 15,000 \\
\hline
\end{tabular}

Source: Compiled based on data obtained from the IBGE (2009)

\section{Results and Discussion}

\subsection{Characterization of Individuals}

By conducting a preliminary analysis of the results of this study, it is noted that the composition of the sample can be considered homogeneous when comparing the gender of the individuals, i.e., $48 \%$ are male and $52 \%$ of females. As for the age of the respondents, the average was around 36 years. Women showed greater frequency in the age range of 40 years $(1.93 \%)$ and men in the age range of 45 years $(2.04 \%)$ (Table 2 ).

The schooling of the respondents varied from 1 to 17 years of study, with $31.2 \%$ and $30 \%$ of women and men, respectively, presented 12 years of studies. The women and men who had been informed of 16 years of study were $15 \%$ and $12.5 \%$, respectively. About $52.8 \%$ of women and $47.2 \%$ of men are married.

The individuals who composed the sample, as to the breed, are classified in white, black, brown, indigenous, yellow and who did not declare their races. It is observed that individuals who consider themselves white totaled 44.5\%; That declared Browns amounted to about 47\%; Blacks totaled $7.7 \%$ and the other, indigenous, yellow and undeclared accounted for $0.8 \%$.

When it relates to the schooling of individuals with the race, $40.4 \%$ of whites have 12 years or more of studies; $29 \%$ of the people who have declared themselves black are also 12 years or more of studies.

Of the sample individuals, $15.3 \%$ of respondents reside in the rural area, and $84.7 \%$ live in the urban area. Of the total that lies in the urban area, $89 \%$ reside in houses and $11 \%$ in Apartments. The inhabitants residing in the rural area presented a greater percentage of the feeling of security about those who live in the urban area, representing $53 \%$ and $47 \%$, respectively. The families residing in the urban area, $27.1 \%$ of these informed that they have about three people residing at home, ratifying the average of individuals per household of the sample that was 3.63 people. Already $23.4 \%$ of the families residing in the rural environment, said that they have about four members at home.

Analyzing the age group of young people between 17 and 29 years who were victims of assaults in which it was used for physical force and violence, it is observed that $42 \%$ of these individuals were assaulted on public thoroughfares. It should also be noted that $91 \%$ of the people who declared themselves white and Brown were mugged on public thoroughfares. Another highlight, in this variable, is that $52 \%$ of young people from 17 to 29 years are women and the remainder $(48 \%)$ are men, and $52 \%$ of the individuals are white and brown, and $27 \%$ are black.

About young people from 17 to 29 years, it was also found that $34 \%$ are married and $70 \%$ do not have children. In general, young and childless couples do not care much about safety, participating in events and passing through the public roads at inappropriate times, which may become the target of the crime, more often. This information is ratified in the preceding paragraph, where $42 \%$ were robbed on the public thoroughfares, also, $50 \%$ of these present sense of security in the city. Another relevant point about the population of 17 to 29 years is that, of the percentage that claimed that it had children, $32.4 \%$ of the people have children under the age of 14 years of age.

Of the couples residing in homes, $23.6 \%$ declared that they had children older than 14 years old and $13.6 \%$ reported that their children were under the age of 14 years. 
In this sense, $23.4 \%$ of these couples with children older than 14 years old, have a sense of security and $14.4 \%$ of couples with children under age 14 feel less safe. This can be explained by the fact that, children with higher age can contribute to the protection of family members. However, families with Young children feel less safe because they fear that their children are victims of robberies, kidnappings or other violent crimes.

As for the feeling of security of the people in the city where he resides, it was found that $49 \%$ of these, who are married, do not feel safe and $51 \%$ of married individuals feel safe in the city. The percentage of women who feel safe is less than men, that is, $49 \%$ of women and $51 \%$ of men have declared that they feel safe in the city.

The Table 3 Relates the average values of individual security are feeling in the city and government spending with public security Per capita For the year 2009, considered the Brazilian regions.

Table 3. The relationship between the feeling of security and spending with public safety per capita

\begin{tabular}{c|c|c}
\hline Region & $\begin{array}{c}\text { The feeling of security } \\
(\%)\end{array}$ & $\begin{array}{c}\text { Public security Expenditure (R } \\
\$)\end{array}$ \\
\hline Northeast & 44,4 & 138,42 \\
Southeast & 49,3 & 198,41 \\
North & 52,8 & 256,41 \\
West & 53,2 & 170,70 \\
Center & 56,4 & 145,35 \\
On &
\end{tabular}

Source: Compiled from data collected by IBGE (2009); STN (2009).

The national average of the feeling of security was $50 \%$, that is, half of the population of the sample feels safe in the city and the average expenditure with public safety in Brazil, in 2009, was R \$183.15. Analyzing Table 3, it is noted that the northeast and Southeast regions were below the national average about the sense of security of the individual. The other regions (North, Midwest, and South) showed a percentage of security sensation above this medium. Concerning the average national spending with public security, the Northeast, Midwest, and South regions were below average. However, it should be emphasized that even presenting a lower per capita average of spending about the other regions, that is, the second smallest, the people of the South region presented an average value of higher security feeling among the Brazilian regions.

\subsection{Security Sensation Analysis}

When estimating the model logit with the purpose of understanding the variables that determine the feeling of security of the individual in the city where he resides, the reference group for the variable dummy race was individual of the white and yellow race, region had as base category the people resident in the south region, victim of assault was the group of individuals who were victim of burglary in residence, type of domicile the reference was the respondent who lives at home and in the case of family type, the base group was made up of people who do not have children.
Table 4. Presents the results of the model's estimation Logit, considering the 2009 data for the Brazilian case.

Table 4. Result of the model Logit, 2009

\begin{tabular}{|c|c|c|c|}
\hline Variables & Coefficients & Default error & Marginal effect \\
\hline $\begin{array}{l}\text { System Security at the } \\
\text { Dom. }\end{array}$ & $-0,3812 * * *$ & 0,0079 & $-0,0950$ \\
\hline $\begin{array}{l}\text { Age (between } 17 \text { and } 29 \\
\text { years) }\end{array}$ & $0,1174 * * *$ & 0,0091 & 0,0293 \\
\hline Sex & $0,1752 * * *$ & 0,0073 & 0,0438 \\
\hline Marital status & $0,0374 * * *$ & 0,0082 & 0,0094 \\
\hline Education & $-0,0256 * * *$ & 0,0010 & $-0,0064$ \\
\hline $\begin{array}{l}\text { Log of household income } \\
\text { Per capita }\end{array}$ & $-0,0818 * * *$ & 0,0097 & 0,0000 \\
\hline Robbery victim & $-1,0145^{* * *}$ & 0,0558 & $-0,2369$ \\
\hline $\begin{array}{l}\text { Resident in the urban } \\
\text { area }\end{array}$ & $-0,6335 * * *$ & 0,0113 & $-0,1550$ \\
\hline Black race & $-0,2434 * * *$ & 0,0143 & $-0,0607$ \\
\hline Brown race & $-0,0792 * * *$ & 0,0084 & $-0,0198$ \\
\hline Northern Region & $-0,6323 * * *$ & 0,0155 & $-0,1549$ \\
\hline Northeast Region & $-0,4400 * * *$ & 0,0124 & $-0,1094$ \\
\hline Midwest Region & $-0,1246^{* * *}$ & 0,0149 & $-0,0311$ \\
\hline Southeast Region & $-0,2963 * * *$ & 0,0128 & $-0,0739$ \\
\hline $\begin{array}{l}\text { Assault victim public } \\
\text { thoroughfares }\end{array}$ & $-0,1806^{* * *}$ & 0,0612 & $-0,0451$ \\
\hline $\begin{array}{l}\text { Victim of arse. Other } \\
\text { Locations }\end{array}$ & $-0,0136^{\mathrm{NS}}$ & 0,0763 & $-0,0034$ \\
\hline $\begin{array}{l}\text { Log of the expense with } \\
\text { Mon. Public Per capita }\end{array}$ & $0,5349 * * *$ & 0,0137 & 0,0032 \\
\hline Type of Home & $0,4997 * * *$ & 0,0136 & 0,1232 \\
\hline $\begin{array}{l}\text { Family with child }<14 \\
\text { years }\end{array}$ & $-0,0930 * * *$ & 0,0131 & $-0,0233$ \\
\hline $\begin{array}{l}\text { Family with son > } 14 \\
\text { years }\end{array}$ & $-0,0569 * * *$ & 0,0127 & $-0,0142$ \\
\hline Another type of family & $-0,0167^{\mathrm{NS}}$ & 0,0136 & $-0,0042$ \\
\hline $\begin{array}{l}\text { Number of people at } \\
\text { home }\end{array}$ & $0,0228 * * *$ & 0,0027 & 0,0057 \\
\hline Constant & $-1,9044 * * *$ & 0,0722 & - \\
\hline
\end{tabular}

Note. *** It denotes significance to $1 \%$; NS not significant.

Source: Compiled based on data obtained from the IBGE (2009)

By Table 4, it is noted that all the variables inserted in the model, except for the representative variables of assault in other places and another type of family, were significant to $1 \%$. as for the signal of the variables, most are according to the expected, and the positive signal increases the feeling of security and the negative decreases the feeling of fear of being the victim of the crime.

The variable home security system presented coefficient negative. It was expected that the individual who had some safety device in his residence (bars on doors and windows of the residence) felt more secure. However, the result shows that the person who has such a device feels less secure. It should be noted that the fact that the domicile presents an additional security system does not prevent the person from being the victim of theft or another type of crime.

The coefficient of the age of the individual showed expected signal, indicating that younger people (age between 17 and 29 years) present a feeling of greater security about individuals of other age groups. By the marginal effect, the young person has the feeling of 
security increased at 2.9 percentage points, kept the remaining variables constant. Such sentiment may be associated with the fact that the young man is more prone to risk, that is, to believe that nothing will ever happen. It is emphasized that according to Waiselfisz [3], homicides among the young population were responsible for $28.8 \%$ of the deaths that occurred in the period 1980 to 2012, while the population not young only $2.0 \%$ of the deaths were caused by murder in the same period.

O Coefficient of Person's sex showed expected signal, shows calling that the male individual is less afraid of being a victim of crime, that is, increases the chance of feeling safer in approximately 4.3 percentage points. In the face of the above, it is noted that women are the people who feel the least safe in your town. A similar result was found by Silva and Beato Filho (2013) in research conducted in Belo Horizonte, where have identified that women are more insecure about the crime. San Juan, Vozmediano, and Vergara emphasize that women, despite demonstrating greater feelings of insecurity, are less the victim of crime compared to men who feel safer, however, present greater cases of victimization.

The variable's marital status has shown positive coefficient, demonstrating that the married person is inserted into the group of individuals who feel safe. This evidences that the married person, having a companion, feel more protected, presenting a greater sense of security, since according to the Cerqueira and Lobão [8], the fact that the subject lives with more people has less chance of being a victim of crime, implying a greater sense of security. Arun and Furtado [15], commit that the individual who has a stable relationship exposes themselves less to risk factors, reducing the possibility of being a victim.

The varying years of schooling indicate that the higher the level of schooling smaller it's a sense of security. Based In this result, it is believed that the person with higher education, earns a better income, accumulating more material goods. Such a situation makes that these individuals are targets most wanted by criminals.

The monthly household income per capita shows that an increase in income reduces the feeling of security of the individual. It should be noted that the income can have an ambiguous effect on the variable object of study, that is, on the one hand, if the person has greater income can invest more in their safety and consequently feel safer, but, on the other hand, individuals with greater power Purchasing can be more targeted by criminals and compose the group of insecure individuals. In the vision of Hicks and Brown [11], the subject with higher yield, by owning more material goods, is more liable to be the victim of the crime, that is, are more attractive targets for thieves.

The variable that represents the victim of theft presented coefficient with negative sign means calling that the subject who has been a victim of the theft has a lesser sense of security compared to people who have not gone through such a situation. The impact of such a variable on the security sublimated is 23.69 percentage points, being the most relevant among the variables inserted in the model.

With the results, it is understood that those who live in the urban area have less sense of security compared to the individuals who reside in the rural environment. The effect of the urban variable on the sense of security is 15.50 percentage points, kept the remaining variables constant. This is since people in the urban area are directly exposed to the risk of crime. However, it cannot be ruled out that residents in the rural area are free from crime.

As in the variable race, the reference was the group of people who declared white and yellow, it is contacted that the subjects of the black and brown race have less sense of security. Analyzing the black and brown race, the chances of safety decrease approximately 6 and two percentage points, respectively, compared to the white and yellow race. An explanation for the effect of the black race being greater may be due to black people normally residing in areas of higher crime risk. Waiselfisz [3] claims that black victimization (percentage of blacks who die more than whites) grew $100.7 \%$ between the years 2002 and 2012, which indicates that blacks are more prone to violence.

The people residing in the north, northeast, Midwest and Southeast regions, about those living in the southern region, the reference group, have demonstrated a lesser sense of security. It is noted that the result is as expected, since mainly the southeast, northeast, and North regions have higher crime rates than the region South, making people feel Less Safe. The greater effect on the feeling of security is of the northern region, around 15 percentage points, followed by the Northeast region with about 11 percentage points. It should be emphasized that in these regions the most violent states and metropolitan regions of Brazil are located, which makes people feel Less secure. According to Waiselfisz [3], the Capitals that presented higher homicide rates (by 100,000) in the total population, from 2002 to 2012, were Christmas, São Luís, Salvador, Fortaleza, Manaus and João Pessoa.

As far as to the coefficients of the victims of assault in the street and other locations (commercial establishment, educational establishment, collective transport, sports centers and others), showed negative signal. However, the second variable was not significant to explain the object of study. Thus, the results indicate that the subjects that have already been mugged on the public roads have a feeling of minor security about the individuals who were victims of assault in residence. The effect of this variable on the feeling of security is approximately 4.5 percentage points. This found can be explained by the fact, in public environments, the risk of being a victim of criminal actions be bigger than in residence raises thus the feeling of insecurity of the individual in transiting through the public roads.

As to the coefficient of the variable spent on public safety, it is understood that it presented a positive result, that is, an increase in a unit in the expenditure safely by the government authorities raises the sense of security as to the crime of the respondent in 0.33 percentage points. This shows the need for the state to invest in public safety, that is, to allocate a larger portion of resources in modern equipment and to invest in qualification and hiring of manpower for the police forces, providing greater security for the citizens.

It was found that the respondent who resides at home feels less safe than the one who lives in apartment or room. This result is according to the expected, seen that the individual who has as home apartment have a greater sense of security in the city since in the apartment it becomes more difficult to access criminals because there is the figure of gatekeepers, security systems, among other 
tools that intimidate criminals. Araújo and Ramos [4] also found a result like the establish that the individual who has as home domicile presents greater insecurity.

As for the composition of the family group (couples and mothers) concerning the existence or not of children, it is noted that respondents who have children under the age of fourteen and the group of people with children over fourteen years of age demonstrate smaller security about those who have no children. It is believed that such a finding is by couples and mothers being afraid that their children may come to be victims of the crime. On the other hand, the group called another type of immediately (couple and mother who have children under the age of fourteen and older) was not significant to explain the feeling of security in the city.

The number of people at home impacts positively on the feeling of security, indicating that the higher the number of individuals in the larger residence right the sense of security since people feel more protected when there are more people in the environment. In this way, the fact of having other people at home diminishes the fear of being a victim of the crime, corroborating the idea posed by Cerqueira and Lobão [8], who claimed that the person who does not live alone tends to be less victimized. in this sense, it is believed that the feeling of security tends to rise.

\section{Final Considerations}

Taking into consideration that the central objective of this study was to analyze the factors that determine the sense of security of people with regard to crime in the year 2009 , it can be concluded that, by the sample of the population studied, that most of the variables were significant, indicating that they were relevant to explain the feeling of security: victim of theft, resident in the urban area, dummy of the northern region, dummy of the northeast region, type of domicile, among other variables that composed the estimated model.

It is noteworthy that the variables victim of theft, individuals residing in the urban area, people who reside in the north and northeast regions, spent with public safety, type of domicile were the ones that had a greater impact on the feeling of security. As far as the first variable is concerned, it is noted that people who have been through a robbery situation fear that the fact is repeated, so they feel less secure. Individuals who live in the urban environment because they are closer to conflict areas and people of bad nature are more prone to criminal actions. However, residents in the rural area are not free from violence and crime.

Individuals resident in the north and northeast regions are more prone to violence and can be explained by the regional aspects and also for some possible effective police reduced in these regions. Although the northern region has a higher average value of expenditure with public security, it was the region that had a greater negative impact on the feeling of security, leading to infer that the role of the public sector, exercised through public security agents, did not is being carried out as expected by the society.

It was found that the variable government spending with public security per capita, was statistically significant, demonstrating that with greater public resources earmarking for public safety will positively affect the sense of security of the citizen in your city. It is noteworthy that, due to the low average of public resources allocated in the security sector in Brazil, the institutions responsible for public safety are left with an obsolete structure, hindering a quality service provision that meets the society's yearnings.

Given this, it is necessary that the Brazilian State develops specific actions/policies of public safety to prevent and combat crime, highlighting the following actions: ostensible policing, use of more equipment modern, skilled agents, installation of cameras in high-risk locations, improvement of public lighting, among others.

Finally, it is noted that by not having data of several periods, it was not possible to deepen the analysis of the studied phenomenon, to verify that the factors that are conditional on the feeling of security are the same over time. Thus, it is suggested that new studies be carried out to confirm the effect of the variables inserted in the model.

\section{References}

[1] BECKER, Gary S. Crime, and Punishment: an economic approach The Journal of Political Economy, v. 76, n.2, p. 169-217, 1968. Disponível em:

<http://www.soms.ethz.ch/sociology_course/becker1968. >.

Acesso em: 25 jun. 2014Institute of Applied Research and Economics (IPEA). 2014. Available at:

$<$ http://www.ipeadata.gov.br/>. Access in: 04 set. 2014.

[2] WAISELFISZ, Julio Jacobo. Map of violence 2014: The young people of Brazil. 2014. Available at:

$<$ Http://www.mapadaviolencia.org.br/pdf2014/Mapa2014 Jovens Brasil.pdf $>$. Access on: 16 out. 2014.

[3] ARAÚJO, Adriano Firmino V. de; RAMOS, Francisco S. Estimation of the loss of well-being caused by crime: the case of the city of João Pessoa - PB. Economy. Brasilia, V. 10, N. 3, p. 577-607, set./nov. 2009.

[4] ALKIMIM, Akenya; CLARKE, Keith C.; OLIVEIRA, Fábio S. Fear, crime, and space: the case of Viçosa, Brazil. Applied Geography, v. 42, p. 124-132, 2013. Available at:

$<$ http://www.sciencedirect.com/science/article/pii/S014362281300 1203\#>. Access on: 02 Jul. 2014.

[5] SANTOS, Marcelo Justus dos; KASSOUF, Ana Lucia. Economic studies of the causes of crime in Brazil: Evidence and controversy. Economy Magazine, Brasilia, v. 9, N. 2, p. 343-372, May/Aug. 2008. Available at:

$<$ Http://www.anpec.org.br/revista/vo19/vo19n2p343_372.pdf. Access on: 15 Jun. 2014.

[6] FOSTER, Sarah; GILES-CORTI, Billie; KNUIMAN, Matthew. Neighborhood design and fear of crime: a social-ecological examination of the correlates of residents' fear of new suburban housing developments.Health \&Place,v.16, n. 6, p. 1156-1165, 2010. Available at:

$<$ http:www.sciencedirect.com/science/article/pii/s1353829210001 097="'> . Access on: 07 Jul. 2014. </http:>

[7] CERQUEIRA, Daniel; LOBÃO, Waldir. Determinants of Crime: a review of theoretical models and empirical results. Rio de Janeiro: IPEA, 2003. (Text for discussion, N. 956).

[8] CARNEIRO, Leandro Piquet. Victimization and public safety management research. Sao Paulo in perspective, v. 21, N. 1, p. $60-$ 75, Jan./jun. 2007.

[9] SAN-JUAN, César; VOZMEDIANO, Laura; VERGARA, Anabel. Self-protective behaviors against crime in urban settings: an empirical approach to vulnerability and victimization models. European Journal of Criminology, v. 9, n.6, p. 652-667, 2012. Available at: <http://euc.sagepub.com/content/9/6/652>. Access on: 21 jun. 2014.

[10] HICKS, Sarah; BROWN, Sarah. Perceptions of risk: A review of the effects of individual and community-level variables on perceptions of risk. International Review of Victimology, v. 19, n. 3, p. 249-267. Available at:

$<$ http://irv.sagepub.com/content/early/2013/07/03/0269758013492 753.full.pdf + html $>$. Access on: 28 jun. 2014. 
[11] HANSLMAIER, Michael. Crime, fear and subjective well-being how victimization and street crime affect fear and life satisfaction.European Journal of Criminology, v.10, n. 5, p. 515533, 2013. Available at:

$<$ http://euc.sagepub.com/content/early/2013/04/30/147737081247 4545.full.pdf="'">.</http:>Access on: 5jul.2014.

[12] LINDSTRÖM, Martinet al. Social capital and neo-materialist contextual determinants of a sense of insecurity in the neighborhood: a multilevel analysis in Southern Sweden. Health \& Place, v.12, p.479-489, 2006. Available at:

$<$ http:www.sciencedirect.com/science/article/pii/s1353829205000 390\#="'> . Access on: 07 Jul. 2014

[13] GUJARATI, Tamer N.; Porter Dawn C. Basic econometrics. Translation of Denise during, Monica Rosenberg and Maria Lucia G. L. Rosa. 5. ed. Porto Alegre: 2011.

[14] MADALOZZO, Regina; FURTADO, Giovanna Maia. A study on victimization for the city of Sao Paulo. Political Economics Magazine, v. 31, N. 1, p. 160-180, Jan./mar. 2011.

[15] BEATO FILHO, Cláudio; PEIXOTO; Betânia Totino; ANDRADE, Mônica Viegas. Crime, Opportunity and victimization. Brazilian Journal of Social Sciences, v. 19, N. 55, Jun. 2004.
[16] Brazilian Institute of Geography and Statistics (IBGE).IBGE States @. Available at: <http: www.ibge.gov.br="'>. Access on: 15 Jun. 2014. $</$ http:>

[17] Brazilian Institute of Geography and Statistics (IBGE).National Search for Households sample 2009:Micro. 2009. Available at: $<$ http:www.ibge.gov.br/home/estatistica/populacao/trabalhoerendi mento/pnad2009/=""'>. Access on: 20 Jun. 2014.

[18] LEAL, José Manuel Pires. The feeling of insecurity in discursividade about crime. Sociologies, N. 23, p. 394-427, Jan./abr. 2012.

[19] MINISTÉRIO DA FAZENDA. Accounting data collection system.Secretary of the National Treasury. 2009. Available at: $<$ https:

www.contaspublicas.caixa.gov.br/sistncon_internet/index.jsp="">. Access on: 12 Jun. 2014.

[20] SILVA, Bráulio Figueiredo Alves da; BEATO FILHO, Claudio Chaves. The social ecology of Fear: evaluating the association between neighborhood context and fear of crime. Brazilian Journal of Population Studies, Rio de Janeiro, v. 30, Sup., p. S155-S170, 2013 